\title{
Household dyeing plants and traditional uses in some areas of Italy
} Paolo Maria Guarrera*

\author{
Address: Museo Nazionale Arti e Tradizioni Popolari, Piazza Marconi 8-10, 00144 Rome, Italy \\ Email: Paolo Maria Guarrera* - pmguarrera@arti.beniculturali.it \\ * Corresponding author
}

Published: 02 February 2006

Journal of Ethnobiology and Ethnomedicine 2006, 2:9 doi:10.1186/1746-4269-2-9

This article is available from: http://www.ethnobiomed.com/content/2/I/9

(C) 2006 Guarrera; licensee BioMed Central Ltd.

This is an Open Access article distributed under the terms of the Creative Commons Attribution License (http://creativecommons.org/licenses/by/2.0), which permits unrestricted use, distribution, and reproduction in any medium, provided the original work is properly cited.
Received: 08 October 2005
Accepted: 02 February 2006

\begin{abstract}
Background: This paper reports the results of investigations carried out from 1977 to today in some areas of Italy (Latium, Marche, Abruzzo and to a limited extent in Sardinia) concerning traditional uses of dyeing plants in the household.

Results: Twenty-nine plants are described, distributed in 23 families, and for each species the vernacular name, the way it is used and the locations of traditional use are given. Other plants used in the past in the above-mentioned regions are recalled.
\end{abstract}

Conclusion: Among the new findings - not mentioned in previous literature, see references - is Muscari neglectum (purplish). Nowadays atavistic dye uses still persist only in Nule (Sardinia).

\section{Background}

This research into a particular field of ethno-botanical traditions - the use of household dyeing plants - was motivated by the wish to preserve the memory of customs that in centuries past expressed the close relationship farmers and shepherds had with nature.

It is well known that dye substances of plant origin present in many wild and cultivated species, were the first to be used by man in this particular craft.

Many plants contain in the second half of their binomial name the word "tinctorius" or its derivatives, which underlines their dyeing properties and their past use in dye-house. They range from lichens to Angiospermae Compositae like Carthamus tinctorius L. and Anthemis tinctoria L., Leguminosae such as Genista tinctoria L., Cruciferae such as Isatis tinctoria L., Boraginaceae such as Alkanna tinctoria (L.) Tausch., Rubiaceae such as Rubia tinctorum L. etc. The first or the second part of the scientific name of many plants refers to the colour imparted by their parts. The Rubia genus reminds us of the reddish colour produced by alizarin, an antraquinonic substance contained in the root, while Reseda lutea L. and Reseda luteola $\mathrm{L}$. remind us of the yellowish colour obtained from the plants.

The Italian names of some plants also show their dyeing properties: e.g. Centaurium erythraea Rafn. is called "biondella" because it bleaches brown hair, Rhamnus saxatilis Jacq. subsp. infectorius (L.) P. Fourn. is called "ranno dei tintori" as it contains antraquinonic dyeing substances, also present in the Rubia genus.

In this paper, in order to contribute to the preservation of the traditional knowledge and uses of plants, we present an overview of the uses of plant dyes collected by a research carried out in the Italian regions Latium, Marche, Abruzzo and Sardinia (Fig. 1). 


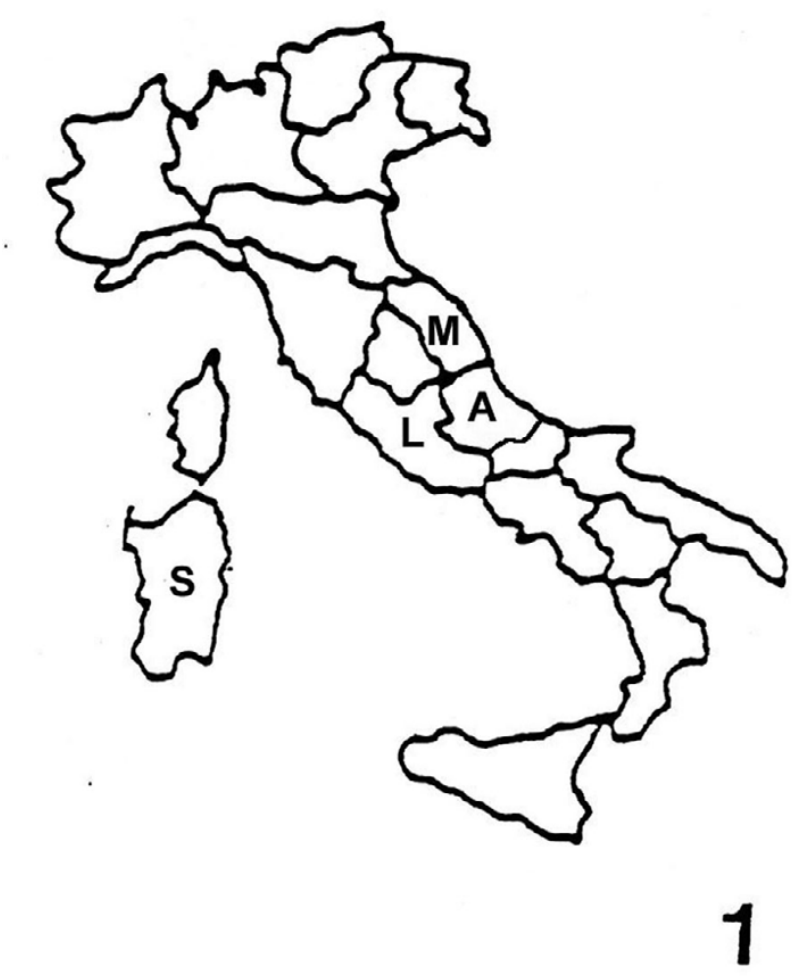

Figure I

Italian areas of the research $(A=$ Abruzzo; $L=$ Latium; $M=$ Marche; $\mathrm{S}=$ Sardinia).

While in Latium, Abruzzo and Marche, the investigations were carried out in large areas, in Sardinia the reported data are limited to a few interviews in the village of Nule.

The areas mentioned have climatic conditions that range from sea level to high mountain (the Apennines). The flora is of Mediterranean and Sub-Mediterranean type, above all near the Tyrrhenian Sea and in the inland areas of Latium, Sardinia and Marche, and of sub-mountainous and mountainous type in the high grounds of Latium, Marche and Abruzzo.

\section{Methods}

Starting in 1977, the investigation was carried out within a larger ethno- botanical research, by interviewing farmers, shepherds and housewives (35 informants, mostly people between 60 and 80 years of age). None of them practiced the art of dyeing apart from some women interviewed in Sardinia. The research was carried out by means of open interviews. The informants were requested to collect specimens of the plants they knew by their vernacular name, or to show the plant species on site. Information was also requested on the methods used to prepare the dyes, also if for several uses no details were obtained (above all in Central Italy), since the dye art was completely lost. Voucher specimens were stored at the Museo Nazionale Arti e Tradizioni Popolari (Rome). The identification and nomenclature of the listed plants were based on Pignatti [1]. In the botanical list of Table 1 are reported for each plant: scientific name, voucher herbarium number, family, vernacular name, parts used, way of use, folk dye uses, colour, regions and localities where the use was collected, number of localities for each use, papers of the author (also in collaboration with other researchers) in which the information is reported [2-8]. Some data are unpublished (= u.d. in Table 1). Photos of some informants interviewed in Nule, with their tipical carpets, were reported in some papers $[5,9]$.

\section{Results and discussion}

The data collected from the interviews show the dyeing properties of 29 plants (see Table 1), listed in alphabetical order and distributed among 23 families. The uses relate to the dyeing mainly wool and cloth for clothing and carpets. The data also show some dyeing traditions of Holy Week (Easter eggs) and, marginally, dyeing customs concerning the cosmetic sector (hair dye, lipstick). Most uses were indicated only by one or two informants; a higher number of informants referred uses for Matricaria chamomilla, Muscari neglectum, Juglans regia and Sambucus nigra.

In Table 1 are described uses of common plants for dyeing in the past and uses of less well-known plants, some of which were used in small dye houses. In some cases, when the plant is quoted only once, its use has often been forgotten or it has been incompletely described, e.g. without mention of the mordants necessary to fix the colour (mordants are chemical substances such as alum or mineral salts combining both with the fiber and with the dye matter). Among the major new findings - not mentioned in previous literature, see references - is Muscari neglectum (purplish). The use of Euphorbia characias (off-white) is described in Italy only for Nule (Sardinia) $[5,10]$. The dye practice of this plant is mentioned in passing by a paper carried out in Greece [11]. Complete and detailed recipes related to Trevi nel Lazio are not reported in other consulted literature. In Abruzzo [3,7,12], in Latium [6] and in Marche $[2,4]$ the uses of the dyeing plants were abandoned at the end of the XIX century or in the first decades of the XX century due to the availability of modern synthetic dyes with some exceptions (in the mountain areas e.g. in Trevi nel Lazio or in some Abruzzo's villages, in the period of the autarchy during the Fascist regime). In Sardinia (Nule, Sassari district) atavistic uses of this type still persist. Such uses are part of pastoral economy with a typical archaic division of the labour within the family nucleus. The shepherd, the head of the household, provides the wool and the women of the family take care of spinning, harvesting wild plants, preparing the dyeing 
Table I: Household dyeing plants in Abruzzo, Latium, Marche and Sardinia regions (Italy)

\begin{tabular}{|c|c|c|c|c|c|c|}
\hline $\begin{array}{l}\text { Binomial name, } \\
\text { vernacular name, } \\
\text { family, voucher } \\
\text { specimen }\end{array}$ & Part used & Way of use & Use & Colour & $\begin{array}{l}\text { Districts, } \\
\text { Localities and } \\
\text { References }\end{array}$ & $N^{\circ} \operatorname{lnf}$. \\
\hline $\begin{array}{l}\text { Allium cepa L. - } \\
\text { Cipolla Liliaceae } \\
\text { (GUI4D) }\end{array}$ & $\begin{array}{l}\text { Leaves or flakes } \\
\text { (bulb) }\end{array}$ & Decoction & To paint Easter eggs & Yellow & $\begin{array}{l}\text { Abruzzo (Teramo } \\
\text { district) [7] }\end{array}$ & 2 \\
\hline $\begin{array}{l}\text { Alnus glutinosa (L.) } \\
\text { Gaertn. - Auzzano } \\
\text { Betulaceae } \\
\text { (GU2D) }\end{array}$ & Bark & Decoction & As a felt dye & Black & Central Latium [6] & I \\
\hline $\begin{array}{l}\text { Anthemis tinctoria } \\
\text { L. - Occhio di Bue } \\
\text { Compositae } \\
\text { (GU4D) }\end{array}$ & Flower heads & Ptisan & As a dye for fabrics & Yellow & $\begin{array}{l}\text { Southern Latium } \\
\text { [6] }\end{array}$ & I \\
\hline $\begin{array}{l}\text { Arctostaphylos uva- } \\
\text { ursi (L.) Sprengel - } \\
\text { Ericaceae (GU7D) }\end{array}$ & Leaves & Decoction & $\begin{array}{l}\text { As a dyeing agent and to tan } \\
\text { leather }\end{array}$ & Not referred & $\begin{array}{l}\text { Abruzzo } \\
\text { (Pacentro) [3] }\end{array}$ & I \\
\hline $\begin{array}{l}\text { Calamintha nepeta } \\
\text { (L.) Savi - } \\
\text { Mentucce Labiatae } \\
\text { (GUI3D) }\end{array}$ & Aerial part & Decoction & As a dyeing agent & Light green & $\begin{array}{l}\text { Abruzzo } \\
\text { (Guardiagrele) [3] }\end{array}$ & 1 \\
\hline $\begin{array}{l}\text { Capsicum annuum } \\
\text { L. Piparioje } \\
\text { (Abruzzo) }\end{array}$ & Leaves & Decoction & As a dye for cloth & Yellow & $\begin{array}{l}\text { Abruzzo (Teramo } \\
\text { district)[7], } \\
\text { southern Marche } \\
{[4]}\end{array}$ & 2 \\
\hline $\begin{array}{l}\text { Solanaceae } \\
\text { (GU25D) }\end{array}$ & & As above & As above & Green & $\begin{array}{l}\text { Abruzzo (Teramo } \\
\text { district) [7] }\end{array}$ & $\mathrm{I}$ \\
\hline $\begin{array}{l}\text { Centaurium } \\
\text { erythraea Rafn }\end{array}$ & Plant in bloom & Decoction & Used by shepherds to dye wool & Greenish yellow & $\begin{array}{l}\text { Abruzzo } \\
\text { (Pacentro) [3] }\end{array}$ & I \\
\hline \multirow[t]{2}{*}{$\begin{array}{l}\text { Biondella (Latium) } \\
\text { Gentianaceae } \\
\text { (GUIID) }\end{array}$} & As above & Decoction & To bleach hair & Yellow & $\begin{array}{l}\text { Abruzzo (Lama dei } \\
\text { Peligni, Luco) [3, } \\
\text { u.d.] }\end{array}$ & 2 \\
\hline & As above & $\begin{array}{l}\text { Concentrated } \\
\text { infusion }\end{array}$ & As above & Yellow & Latium (Anzio) [6] & $\mathrm{I}$ \\
\hline $\begin{array}{l}\text { Daphne gnidium L. } \\
\text { Su Truiscu } \\
\text { Thymelaeaceae } \\
\text { (GU27D) }\end{array}$ & $\begin{array}{l}\text { Stem and leaves, } \\
\text { cut into small } \\
\text { pieces }\end{array}$ & Decoction & $\begin{array}{l}\text { Plant parts are boiled in water for } \\
\text { about } 2 \text { hours, adding some alum } \\
\text { for a yellow-green shade or lime } \\
\text { for a pale yellow. Wool is boiled in } \\
\text { the filtered mixture for half an } \\
\text { hour. It is left to stand in the } \\
\text { covered container till the } \\
\text { following day. }\end{array}$ & $\begin{array}{l}\text { Yellow-green and } \\
\text { soft-yellow. More } \\
\text { intense shades are } \\
\text { obtained with older } \\
\text { plants }\end{array}$ & Sardinia (Nule) [5] & 2 \\
\hline $\begin{array}{l}\text { Euphorbia characias } \\
\text { L. Ua } \\
\text { Euphorbiaceae } \\
\text { (GU8D) }\end{array}$ & Aerial part & See "use" & $\begin{array}{l}\text { It is boiled in a cauldron in } \\
\text { moderate doses for not longer } \\
\text { than an hour as it is highly toxic } \\
\text { (the sharp and irritating smoke, } \\
\text { should not be inhaled). Wool is } \\
\text { added, boiled for } 30 \text { and left to } \\
\text { cool in the covered cauldron. }\end{array}$ & $\begin{array}{l}\text { Very persistent off- } \\
\text { white }\end{array}$ & Sardinia (Nule) [5] & 2 \\
\hline $\begin{array}{l}\text { Fraxinus excelsior L. } \\
\text { Frassino Oleaceae } \\
\text { (GUI7D) }\end{array}$ & $\begin{array}{l}\text { Leaves and } \\
\text { walnut husks } \\
\text { with ivy leaves } \\
\text { (and, if available, } \\
\text { berries) }\end{array}$ & $\begin{array}{l}\text { Maceration in } \\
\text { water }\end{array}$ & $\begin{array}{l}\text { Used to dye some types of cloth } \\
\text { after a day soaking in water. Ivy } \\
\text { provides colour and its saponins } \\
\text { dissolve the plants dyeing } \\
\text { substances in the water and make } \\
\text { them more easily absorbed by } \\
\text { cloth. }\end{array}$ & Lasting dark green & $\begin{array}{l}\text { Latium (Trevi nel } \\
\text { Lazio) [6] }\end{array}$ & 1 \\
\hline $\begin{array}{l}\text { Fraxinus ornus L. } \\
\text { Ornello Oleaceae } \\
\text { (GUI8D) }\end{array}$ & Bark of branches & Decoction & As a wool dye & $\begin{array}{l}\text { Greenish-yellow or } \\
\text { apple-green }\end{array}$ & Central Latium [6] & I \\
\hline $\begin{array}{l}\text { Hedera helix L. } \\
\text { Ellera Araliaceae } \\
\text { (GUID) }\end{array}$ & Fruits & Juice & $\begin{array}{l}\text { As a dye for clothes (see } F \text {. } \\
\text { excelsior) }\end{array}$ & Brown & $\begin{array}{l}\text { Latium (Farnese, } \\
\text { Trevi nel Lazio) [6] }\end{array}$ & 2 \\
\hline
\end{tabular}


Table I: Household dyeing plants in Abruzzo, Latium, Marche and Sardinia regions (Italy) (Continued)

\begin{tabular}{|c|c|c|c|c|c|c|}
\hline & Leaves & Decoction & $\begin{array}{l}\text { To wash delicate clothes and } \\
\text { brighten the colour }\end{array}$ & & $\begin{array}{l}\text { Abruzzo } \\
\text { (Penne)[u.d.], } \\
\text { Latium [6] }\end{array}$ & $\begin{array}{l}1 \\
6\end{array}$ \\
\hline $\begin{array}{l}\text { Isatis tinctoria L. } \\
\text { Cruciferae } \\
\text { (GU6D) }\end{array}$ & Aerial parts & $\begin{array}{l}\text { Not referred } \\
\text { (N.r.) }\end{array}$ & As a dyeing agent for cloth & Yellow green & Abruzzo [8] & N.r. \\
\hline $\begin{array}{l}\text { Juglans regia } \mathrm{L} . \\
\text { Noce }\end{array}$ & Husks & $\begin{array}{l}\text { Maceration/ } \\
\text { decoction }\end{array}$ & As a dyeing agent for wool & Black & Sardinia (Nule) [5] & 2 \\
\hline \multirow[t]{3}{*}{$\begin{array}{l}\text { Juglandaceae } \\
\text { (GUI2D) }\end{array}$} & Roots & $\begin{array}{l}\text { Decoction }(30- \\
\left.60^{\prime}\right)\end{array}$ & As a dye for clothes & Lasting brown & $\begin{array}{l}\text { Latium (Staffoli) } \\
\text { [6] }\end{array}$ & 1 \\
\hline & Leaves, husks & $\begin{array}{l}\text { Decoction/ } \\
\text { Maceration }\end{array}$ & As above & Brown & $\begin{array}{l}\text { Abruzzo (Majella } \\
\text { and Teramo } \\
\text { districts) }[3,7] \text {, } \\
\text { Latium [6], Marche } \\
{[2]}\end{array}$ & 10 \\
\hline & Leaves, husks & $\begin{array}{l}\text { Decoction/ } \\
\text { Maceration }\end{array}$ & $\begin{array}{l}\text { As a dyeing agent for hair } \\
\text { (women) }\end{array}$ & Brown & $\begin{array}{l}\text { Abruzzo (Majella } \\
\text { district) [3], } \\
\text { Southern- } \\
\text { CentralLatium [6] }\end{array}$ & 4 \\
\hline $\begin{array}{l}\text { Linaria vulgaris } \\
\text { Miller } \\
\text { Scrophulariaceae } \\
\text { (GU24D) }\end{array}$ & Aerial part & Ptisan & As a dyeing agent for cotton cloth & Yellow & Central Latium [6] & I \\
\hline $\begin{array}{l}\text { Lycopersicon } \\
\text { esculentum Miller } \\
\text { Pemmadore- } \\
\text { Solanaceae } \\
\text { (GU26D) }\end{array}$ & Leaves & Ptisan & As a dye for cloth & Green & $\begin{array}{l}\text { Abruzzo (Penna- } \\
\text { piedimonte) [3] }\end{array}$ & I \\
\hline \multirow{2}{*}{$\begin{array}{l}\text { Matricaria } \\
\text { chamomilla L. } \\
\text { Capomilla } \\
\text { Compositae } \\
\text { (GU5D) }\end{array}$} & $\begin{array}{l}\text { Flower heads (I/ } \\
2 \mathrm{~kg}-\mathrm{I} \mathrm{kg)}\end{array}$ & $\begin{array}{l}3 \text { hour } \\
\text { decoction }\end{array}$ & To dye wool & Yellow & $\begin{array}{l}\text { Abruzzo (Majella } \\
\text { district) [3] }\end{array}$ & I \\
\hline & Flowers & $\begin{array}{l}\text { Highly } \\
\text { concentrated } \\
\text { decoction }\end{array}$ & To bleach hair & Yellow & $\begin{array}{l}\text { Abruzzo[3], } \\
\text { Latium [6], Marche } \\
\text { [u.d.] }\end{array}$ & 6 \\
\hline $\begin{array}{l}\text { Morus nigra L. } \\
\text { Gelso - Moraceae } \\
\text { (GUI6D) }\end{array}$ & Wood & Decoction & To dye wool & $\begin{array}{l}\text { Opaque olive- } \\
\text { yellow }\end{array}$ & Latium [6] & I \\
\hline $\begin{array}{l}\text { Muscari neglectum } \\
\text { Guss. ex Ten. } \\
\text { Pignolo, Pignocco } \\
\text { Liliaceae (GUI5D) }\end{array}$ & $\begin{array}{l}\text { Flowery aerial } \\
\text { part }\end{array}$ & Decoction & $\begin{array}{l}\text { During Holy Week eggs were } \\
\text { boiled with plant parts to make } \\
\text { Easter Eggs. }\end{array}$ & Purplish & $\begin{array}{l}\text { Southern-central } \\
\text { Marche }[4, \text { u.d.] }\end{array}$ & 3 \\
\hline $\begin{array}{l}\text { Papaver rhoeas } \mathrm{L} \text {. } \\
\text { Papambre }\end{array}$ & Petals & Decoction & $\begin{array}{l}\text { It was used sometimes to dye } \\
\text { fabric. }\end{array}$ & Red & $\begin{array}{l}\text { Abruzzo [3, } \\
\text { Latium [6] }\end{array}$ & 2 \\
\hline $\begin{array}{l}\text { Papaveraceae } \\
\text { (GUI9D) }\end{array}$ & Buds and petals & & Used as lipstick and rouge & & $\begin{array}{l}\text { Abruzzo [u.d.], } \\
\text { Latium [6] }\end{array}$ & 2 \\
\hline $\begin{array}{l}\text { Parietaria diffusa } \\
\text { Merth. et Koch - } \\
\text { Palatana } \\
\text { Urticaceae } \\
\text { (GU28D) }\end{array}$ & Aerial part & Ptisan & $\begin{array}{l}\text { Used in remarkable quantities to } \\
\text { dye hemp sacks or faded green } \\
\text { clothes. }\end{array}$ & Intense green & $\begin{array}{l}\text { Abruzzo } \\
\text { (Pacentro) [3] }\end{array}$ & I \\
\hline $\begin{array}{l}\text { Pinus halepensis } \\
\text { Miller Pino } \\
\text { Pinaceae (GU20D) }\end{array}$ & Bark & Decoction & $\begin{array}{l}\text { To dye fishermen's nets (up to } \\
\text { WWII) }\end{array}$ & Reddish & Marche [4] & 1 \\
\hline $\begin{array}{l}\text { Populus nigra L. } \\
\text { Pioppo Salicaceae } \\
\text { (GU23D) }\end{array}$ & $\begin{array}{l}\text { Fresh bark of } \\
\text { young branches }\end{array}$ & Decoction & $\begin{array}{l}\text { After one hour boiling, the wool } \\
\text { was immersed for a further } 30 \\
\text { minutes }\end{array}$ & Golden yellow & Central Latium [6] & I \\
\hline $\begin{array}{l}\text { Quercus cerris L. } \\
\text { Cerro Fagaceae } \\
\text { (GU9D) }\end{array}$ & Bark & Decoction & As a dyeing agent & Very dark & Abruzzo [3] & 1 \\
\hline $\begin{array}{l}\text { Quercus pubescens } \\
\text { Willd. - Cerqua }\end{array}$ & Bark & Decoction & As a dyeing agent & Very dark & $\begin{array}{l}\text { Abruzzo[3,7], } \\
\text { Marche [2] }\end{array}$ & 3 \\
\hline \multirow[t]{2}{*}{ Fagaceae (GUIOD) } & Bark/Galls & Decoction & As a dyeing agent & Very dark & Abruzzo [7] & I \\
\hline & Galls & Juice & As ink & Very dark & Marche [2] & I \\
\hline
\end{tabular}


Table I: Household dyeing plants in Abruzzo, Latium, Marche and Sardinia regions (Italy) (Continued)

\begin{tabular}{|c|c|c|c|c|c|c|}
\hline $\begin{array}{l}\text { Rhamnus alaternus } \\
\text { L. Su Laru } \\
\text { Rhamnaceae } \\
\text { (GU2 ID) }\end{array}$ & $\begin{array}{l}\text { Bark gathered in } \\
\text { spring }\end{array}$ & Decoction & $\begin{array}{l}\text { The dried bark is set to boil for an } \\
\text { entire day while water is added to } \\
\text { compensate for evaporation. In } \\
\text { the evening, wool is dipped into } \\
\text { the cauldron and sprinkled with } \\
\text { ash. }\end{array}$ & Brown & Sardinia (Nule) [5] & 2 \\
\hline $\begin{array}{l}\text { Rubia peregrina L. } \\
\text { Sa Ruza Rubiaceae } \\
\text { (GU22D) }\end{array}$ & $\begin{array}{l}\text { Roots are still } \\
\text { used, prefera-bly } \\
\text { of plants grown } \\
\text { in sunny areas. }\end{array}$ & See "use" & $\begin{array}{l}\text { The woody part is removed from } \\
\text { the washed roots. The roots are } \\
\text { crushed to a pulp and boiled in } \\
\text { water for about } 4 \text { hours. Wool is } \\
\text { added and left to boil for a further } \\
30 \text { '. This procedure results in a } \\
\text { pink shade. To obtain a shade } \\
\text { between "dark rust" and brown, } \\
\text { the wool is placed in a wide } \\
\text { container, sprinkled with ash and } \\
\text { covered liquid obtained from the } \\
\text { decoction. It needs constant and } \\
\text { careful stirring. }\end{array}$ & See "use" & Sardinia (Nule) [5] & 2 \\
\hline Sambucus nigra L. & Flowers & Decoction & To dye white doilies & Dark yellow & Latium [6] & 1 \\
\hline Zambuco & Fruits & Juice & As a dyeing agent for must & Blackish & Abruzzo [7] & 2 \\
\hline $\begin{array}{l}\text { Caprifoliaceae } \\
\text { (GU3D) }\end{array}$ & Fruits & Juice & As ink & Blackish & $\begin{array}{l}\text { Abruzzo [7], } \\
\text { Latium [6], Marche } \\
\text { [2] }\end{array}$ & 9 \\
\hline Urtica dioica L. & Root & Ptisan & To dye cloth & Yellow & Latium [6] & I \\
\hline $\begin{array}{l}\text { Ortica Urticaceae } \\
\text { (GU29D) }\end{array}$ & Leaves & Decoction & To paint Easter eggs & Green & $\begin{array}{l}\text { Central Marche } \\
\text { [2] }\end{array}$ & I \\
\hline
\end{tabular}

decoctions, dyeing and weaving on vertical looms [5]. In Nule Rhamnus alaternus, Rubia peregrina, Euphorbia characias and Daphne gnidium are still used. For Sardinia, a region with few contacts with other cultures, the consulted bibliography on local folk traditions provides other details or mentions some of the uses quoted in Table 1. Curreli and Loddo [13] report that in Sardinia "to obtain black dye usually the yarn was boiled together with the roots of the grass named "truiscu" in Campidano dialect and "truvuzu" in Logudoro dialect (Daphne gnidium)." Also Cabiddu [14] speaks about the same grass used for obtaining a black colour, named "truiscu", from the Latin 'turbiscus' and from the Spanish "torvisco". Atzei [10] claimed that $D$. gnidium is perhaps the most used dye plant in Sardinia.

Many other plants not cited in this study are reported for this region. Cabiddu [14] reports the use of the boiled peel of Punica granatum L. for yellow dye, and the use for other colours of the leaves of Myrtus communis L., of wild blackberries, of fresh walnut-husk etc. Curreli and Loddo [13], speaking of miscellaneous dye plants of Sardinia, also name the dye uses of alder, oak and pomegranate bark, of myrtle leaves and of prickly pear, ivy, rosemary, and briar. Atzei reports for Sardinia the same dye plants and many others, 111 in total [10]. Cabiddu [14] names Rubia tinctorum but not $R$. peregrina. The use of the Rubia peregrina root is to be associated with the better-known one of Rubia tinctorum, cultivated since ancient times and called "garance" in France [15]. They both share dyeing antraquinones. The roots of Rubia peregrina, grown in sunnier zones, contain a greater quantity of dyeing substances, according to an informant in Nule. "The red, that assumed a rather dark shade, was obtained from the roots of ...Rubia tinctorum, or from boiling the fibres with a mixture of bramble buds, locusts, mastic-tree, yew-tree bark and of fresh nuts (...)". A brighter red was obtained in the south of the island boiling Alkanna tinctoria [14]. The use of the wild madder roots, at least 3 years old, is documented for Abruzzo. The wool was first boiled with alum and cream of tartar; it was then boiled in a cauldron for 12 hours with a paste of crushed and dried madder, according to intensity of colour desired [15]. Shades of red (from crimson to pink and rose) were obtained by adding the appropriate concentrations of ashes from the fireplace [11].

Rhamnus alaternus, used in Nule and quoted also by Atzei [10] and by Bruni et al. [17] is closely related to Rhamnus saxatilis subsp. infectorius, called in Italian "ranno dei tintori" [1] that contains analogous dyeing antraquinones. Among the other dye plants of Sardinia: to dye yellow, alder (Alnus sp.) leaves were usually used (see the reported use in Latium, confirmed also by Schneider [18]). Chelidonium majus L. leaves, Chrozophora tinctoria (L.) A. Juss., Crocus sativus L. and Daphne gnidium fruit gave a yellow closer in shade to mustard. Rust was another common colour: it was obtained from the berries of the yew-tree or from ash leaves mixed with flakes of rusted iron. Dark brown, verging on reddish, was obtained from Cynomo- 
rium coccineum L. Finally, the blue dye was obtained from Mercurialis annua L. and from the infusion of Haematoxylon champechianum L., a type of wood imported from Central America. Wild saffron (Crocus sp.), mentioned for Sardinia by Curreli and Loddo [13], was used to dye the silk handkerchief of the women of Orgosolo wore during the feast of St. John the Baptist on the $24^{\text {th }}$ June, a propitious and magic day against moths [19]. This custom resembles Roman and Greek women favour for saffron yellow clothing [18]. The traditional shades, obtained prevalently from plants and minerals, were fewer than that of the today's synthetic dyes [13]. Recently many dye plants (Alnus glutinosa, Chrozophora tinctoria, Daphne gnidium, Hedera helix, Punica granatum, Quercus ilex etc.) were quoted for Sardinia [10,17].

Pastel (Isatis tinctoria) is a dye plant for which field information was scarce. It is very common along roads, in meadows and uncultivated fields and near built-up areas (e.g. near L'Aquila), in a sinanthropic context, in Abruzzo. In Latium however, it is considered as rather rare. A "Guild of the Pastel" existed in Rieti (Latium) from the Middle Ages to the XVIII century. Pastel was once cultivated in large quantities in the Rieti district to dye wool blue after fermentation [6]. In Scanno (Abruzzo), warm solutions of ashes from the fireplace were used to fix the colour [12]. It seems that the Umbrian town of Gualdo Tadino derives its name from the abundance, in times past, of the plant ("guado") in the surrounding area. Guarino et al. [20] describe the economic importance it had in southern Italy. Schneider [18] reports that the earliest recipe of dyeing with pastel, preserved in the papyruses of Leiden and of Stockholm, dates back to the III century A.D. The methods described include maceration in urine, cooking and addition of soapwort and orchil. It is probable that in ancient times numerous dyes were prepared by maceration without boiling. This was still the case for pastel and indigo in the last centuries of the modern era. Softening with alum (imported from Turkey) or tartar from barrels was introduced [15] to make the colour obtained by boiling plant parts more lasting.

Madder was one of the first plant substances to be treated.

Madder is already mentioned by Pliny the Elder in the $1^{\text {st }}$ century A.D., its cultivation, already mentioned by Pliny, was encouraged and supported by Charlemagne [16].

The use of Pinus halepensis bark to dye red nets of fishermen is confirmed by Fenaroli [21], while in Corsica similarly Pinus nigra Arnold subp. laricio Maire and P. pinaster Aiton were used as dye plants for nets [10].

The research carried out brought also to light dyeing customs of Holy Week. Wild Muscari neglectum, picked at the beginning of spring and boiled with Easter eggs dyes them a purplish blue and nettle leaves (its chlorophyll) green while wrapping in onion skin (Allium cepa) colours the eggs yellow (customs of Marche). In Trentino-Alto Adige Muscari racemosum (L.) Miller was also used to dye the eggs purplish [22]. In Abruzzo Easter Eggs were dyed a purplish blue by boiling them with wild violets $[16,23]$.

Other information on the dye traditions in Abruzzo relating to fabrics was obtained from the last cited texts. In Scanno locks of wool were dyed with Indigofera tinctoria first, then with Fraxinus ornus leaves and the cloth assumed a dark-green colour that never lost its brightness. Tammaro [12] notes for Abruzzo the use of Rhus coriaria L. stem bark (yellow) and root bark (brown), of Scabiosa atropurpurea (L.) Greuter et Burdet, for a pea-green dye, of Rhamnus cathartica L. fruits to colour cotton cloth and leather goods in warm shades. He confirms the use of Rubus fruticosus roots (yellow) and Juglans regia husks (decoction of the fermented liquid for 10 days to confer a lasting green). As to Quercus sp.pl., oak bark and the first transparent onionskins mixed with soot were used to dye socks [16]. Schneider [18] writes about oak bark and material containing tannins, he adds that in the Middle Ages, iron and tannins (from galls and oak bark) were largely used to obtain a black colour.

Some texts $[12,24]$ name other dye plants used in Latium and Abruzzo: Calendula arvensis that dyed yellow using alum as a softener; Salix alba, the liquid of which, obtained by boiling the bark or the leaves, dyed wool yellow; Ulmus minor, the bark and leaves of which were used in decoction, with the addition of alum, to dye wool red. These are plant cited for their dye properties also in Sardinia [10].

It is to be underlined that all the plants described in Table 1 are wild with the exception of 5 (Juglans regia, Allium cepa, Morus nigra, Lycopersicon esculentum, Capsicum annuum). It can be reasonably assumed that their dyeing properties were discovered by chance and have been exploited since antiquity.

In Italy a route with dye living plants (some of them cited in this research) and related recipes were predisposed near the Botanical Garden in Modena [25]. The interest for this topic is testified by recent specific texts $[26,27]$.

Özgökçe and Yilmaz [28] listed 50 taxa for East Anatolia, while Doğan et al. [29] named 123 taxa for the whole Turkey, several of which are typical of these districts or endemic species, while others are also cited for Italy. Among these last: Allium cepa, Reseda lutea, Rubia tinctorum, Juglans regia. Several genuses of dye plants are in 
common (e.g. Euphorbia, Rhamnus etc.), also if different dye species are described for Italy and Turkey.

\section{Conclusion}

Comparisons could be extended to other world areas [3040].

Nowadays dye uses still persist only in Nule (Sardinia), but many dye plant uses are still remembered and practised in this region, on the basis of a more in depth research [10]. In Central Italy dye use has often been forgotten or it has been incompletely described:

for this reason for several uses have no details.

Among the plant uses with a higher number of informants those concerning Matricaria chamomilla, Muscari neglectum, Juglans regia and Sambucus nigra, but Isatis tinctoria, Fraxinus ornus and Rubia peregrina $[3,6,11]$ were in the past (until the second World War) the most important dye plants of the same area.

One hopes that this research carried out into old dyeing uses can contribute to a preservation of traditional knowledge for possible future artisan activities that may be sources of some income in local enterprises. Preserving the memory of the techniques used in the past, enables us to obtain once again today the original shades and the soft tonalities of colour that for many centuries characterized carpets and cloths dyed with traditional plant substances.

\section{Acknowledgements}

The author wishes to express his gratitude to Dr. Nicoletta Tinozzi and to Dr. Penny Watson for the revision of the English language.

\section{References}

I. Pignatti S: Flora d'Italia Volume I-3. Bologna: Edagricole; 1982.

2. Guarrera PM: Ricerche etnobotaniche nelle province di Macerata e di Ancona. Rivista Italiana EPPOS 198I, 2:99-108. 4: 220228.

3. Guarrera PM: Usi tradizionali delle piante nel territorio della Majella. Rivista Abruzzese. Fascic. Monograf. su Erbe e Piante Medicinali nella Storia e nelle Tradizioni Popolari Abruzzesi 1987:17-44. Centro Servizi Culturali Regione Abruzzo. Chieti. Off. Grafiche Anxanum, Lanciano.

4. Guarrera PM: Usi tradizionali delle piante in alcune aree marchigiane. Inform Bot It 1990, 22(3): 155-167.

5. Guarrera PM: Tinture vegetali ancora oggi usate in Sardegna nell'antica arte tessile. Natura e Montagna 1990, 39(3-4):9-12.

6. Guarrera PM: II Patrimonio Etnobotanico del Lazio Roma: Dipartimento di Biologia Vegetale Università "La Sapienza" e Assessorato alla Cultura Regione Lazio; 1994.

7. De Simoni E, Guarrera PM: Indagine Etnobotanica nella provincia di Teramo. Quad Botanica Ambientale Appl 1994, 5:3-10.

8. Guarrera PM, Tammaro F: Ethnobotanical research in the Abruzzo and Latium (Central Italy). Actes du ler Colloque Européen d'Ethnopharmacologie. Ethnopharmacologie: Sources, Methodes, Objectifs (Societé Francaise d'Ethnopharmacologie) - W.H.O. - O.M.S. Metz, 23-25.3.1990. Editions de I'ORSTOM I991:168-170.

9. Guarrera PM: Le piante di uso domestico e artigianale. In $\mathrm{La}$ Biologia Vegetale per i Beni Culturali Volume II. Edited by: Caneva G. Conoscenza e Valorizzazione, Firenze, Nardini; 2005:357-360.
10. Atzei AD: Le piante nella tradizione popolare della Sardegna Sassari: C. Delfino; 2003.

II. Tammaro F, Xepapadakis G: Plants used in phytotherapy, cosmetics and dyeing in the Pramanda District (Epirus, NorhWest Greece). J Ethnopharmacol 1986, 16:167-174.

12. Tammaro F: Flora Officinale d'Abruzzo Chieti: Centro Servizi Culturali Regione Abruzzo; 1984.

13. Curreli E, Loddo P: La tessitura. In II lavoro dei sardi Ed Gallizzi, Sassari; 1983:I|7-|4|.

14. Cabiddu G: Usi, costumi, riti, tradizioni popolari della Trexenta Cagliari: Editrice Sarda Fossataro; 1965:588-590.

15. Jaoul M, Arveiller V, Colinart S, Garnier N, Margerie A, Pannequin B, Romano M: Des teintes et des couleurs Volume 25-49. Catalogue. Les dossiers du Musée national des arts et traditions populaires 2. Ministère de la Culture et de la Communication. Paris: Editions de la Réunion des musées nationaux; 1988:105-II0.

16. De Nino A: Usi Abruzzesi, I 88I Volume II. Ristampa dell'edizione Barbera, Firenze: Olschki; 1963:121-124.

17. Bruni A, Ballero M, Poli F: Quantitative etnnopharmacological study of the Campidano valley and Urzulei district, Sardinia, Italy. J Ethnopharmacol 1997, 57:97-I 24.

18. Schneider G: Tingere con la natura Milano: Ottaviano; I98I.

19. Campanelli R: Storia minima, usi e curiosità dello zafferano in Sardegna. Lo zafferano. Atti del Convegno Internazionale. L'Aquila 1989:297-300. 27-29 ottobrel 989

20. Guarino C, Casoria P, Menale B: Cultivation and use of Isatis tinctoria L. (Brassicaceae) in Southern Italy. Economic Botany 2000, 54(3):395-400.

21. Fenaroli L: Gli alberi d'Italia Martello, Milano; 1967.

22. Pedrotti G, Bertoldi V: Nomi dialettali delle piante indigene del Trentino e della Ladinia dolomitica. Presi in esame dal punto di vista della botanica della linguistica e del folklore Trento: Ed. G. Monauni; 1930.

23. De Nino A: Usi Abruzzesi; 1897 Volume VI. Ristampa dell'edizione Barbera. Firenze: Olschki; 1965:83-84.

24. Monterumici D: Alcune notizie statistiche, topografiche, agricole sul circondario di Cittaducale provincia dell'Aquila Treviso, Zoppelli; I876:20-2I.

25. Sgarbi E, Baroni Fornasiero R, Dallai D: Le piante tintorie dell'Orto Botanico di Modena. Atti $99^{\circ}$ Congresso Società Botanica Italiana. Torino :264. 22-24 settembre 2004

26. Marotti M: Le piante coloranti Edagricole, Bologna; 1997.

27. Mearelli F, Giogli A: Le piante tintorie nella colorazione dei capelli Ed. Aboca, Sansepolcro (AR); 2003.

28. Özgökçe F, Yilmaz I: Dye plants of East Anatolia region (Turkey). Econ Bot 2003, 57(4):454-460.

29. Doğan $Y$, Süleyman B, HüseyinMert H, Ay G: Plants used as natural dye sources in Turkey. Econ Bot 2004, 57(4):442-453.

30. Antunez De, Mayolo KK: Peruvian Natural Dye Plants. Econ Bot 1989, 43(2): $|8|-|9|$.

31. Cardon D: Guide des teintures naturelles Lausanne, Delachaux et Niestlé; 1990.

32. Bolton EM: Lichens for Vegetable Dyeing Sudio Vista Publishers, London; 1960.

33. Bliss A: North American Dye Plants Loveland, Interweave Press; 1993.

34. Bliss A: A Handbook of Dyes from Natural Materials New York, Scribner; 198I.

35. Cannon J: Dye Plants and Dyeing Portland, Timber Press; 1994.

36. Jacobs BE: Growing Herbs and Plants for Dyeing Tarzana, Select Books; 1977.

37. Goodwin J: A Dyer's Manual London, Pelham Books; 1982.

38. Lesch A: Vegetable Dyeing: I5 / Color Recipes for Dyeing Yarns and Fabrics with Natural Materials New York, Watson-Guptill Publications; 1970.

39. McRae BA: Colors from Nature: Growing, Collecting, and Using Natural Dyes Pownal, Storey Communications; 1993.

40. Zanoni TA: Dyes From Plants: An Annotated List of References Bronx, Council on Botanical and Horticultural Libraries; 1983. 